\title{
ОЦНКА СТАНУ ФЕТОПЛАЦЕНТАРНОГО КОМПЛЕКСУ У ВАГІТНИХ ІЗ ГЕНІТАЛЬНИМ ГЕРПЕСОМ ТА ВІРУСОМ ЦИТОМЕГАЛІЇ
}

ДВНЗ «Ужгородський національний університет»

Резюме. Функціональний стан фетоплацентарного комплексу (ФПК) у вагітних із генітальним герпесом та вірусом цитомегалії супроводжується розвитком плацентарної дисфункції, яка формується на 18-20-му тижні та клінічно проявляється в другому та третьому триместрі вагітності. Клінічно це проявляється тахікардією у внутрішньоутробного плода (з $12,0 \%$ до $29,4 \%$ ); зміною дихальної (з $16,0 \%$ до $26,4 \%$ ), рухової активності ( $12,0 \%$ до $36,3 \%$ ) та тонусу плода (з $4,0 \%$ до $8,8 \%$ ); передчасним старінням плаценти (3 $20,0 \%$ до $47,1 \%$ ),

Вступ. Наявність генітальних інфекцій під час вагітності (герпесвірусної) у багатьох випадках веде до деструктивних змін плаценти, що, у свою чергу, спричиняє порушення життєдіяльності внутрішньоутробного плода [4]. При інфікуванні вагітної в другому і третьому триместрах вагітності, у першу чергу, виникають зміни в плаценті і / або навколоплідних оболонках [3]. Численні дослідження авторів свідчать про розвиток плацентарної дисфункції при генітальному герпесі та цитомегаловірусній інфекції, ступінь проявів яких залежить від терміну гестації і тривалості рецидивів захворювання [2]. У період імплантації і раннього ембріогенезу при інфікуванні вагітної герпетичною інфекцією виникає первинна плацентарна дисфункція, яка призводить до мимовільного переривання вагітності, викиднів, що не відбулися в ранні терміни гестації. У другому та третьому триместрах вагітності розвивається синдром затримки розвитку плода, органічні зміни в плаценті, зміни матковоплацентарно-плодового кровотоку [1].

Мета дослідження. Дослідити стан фетоплацентарного комплексу у вагітних 3 генітальним герпесом та вірусом цитомегалії.

Матеріал і методи. Проаналізовано ультразвукові, доплерометричні показники, зміну рівня гормонів фетоплацентарного комплексу (ФПК) у вагітних із генітальними інфекціями. Для виконання поставленої мети всі вагітні були розподілені на дві групи: I - контрольну (КГ) - сформували здорові вагітні, без наявності генітальних інфекцій та соматичної патології (35 жінок); II групу - сформували 50 жінок із завмерлою вагітністю в анамнезі, які є носіями HSV та CMV інфекції. Ведення вагітних здійснювалось відповідно до Наказів MO3 України (№ 417 від 15.07.2011 р. „Про організацію амбулаторної акушерсько-гінекологічної допомоги в Україні та № 906 «Про затвердження клінічного протоколу 3 акушерської допомоги "Перинатальні інфекції"» від 27.12.2006 року). Показники функціонального стану плода, що включали динаміку зміною кількості навколоплідних вод (маловоддя 3 $8,0 \%$ до $23,5 \%$ та багатоводдя $310,0 \%$ до $35,3 \%$ ) на тлі виражених гемодинамічних порушень у ФПК (порушення кровообігу в артерії пуповини та маткових артеріях); зміною рівня гормонів ФПК - зниження вмісту естріолу, прогестерону, хоріонічного гонадотропіну і плацентарного лактогену, на тлі збільшення рівня кортизолу.

Ключові слова: вірус герпесу, цитомегаловірус, вагітність, фетоплацентарний комплекс.

ехографічних та фетометричних змін та порушення матково-плацентарного і фетоплацентарного кровотоку, проводили за допомогою ультразвукового дослідження в 1-, 2-му та 3-му триместрах вагітності. Ехографічні та доплерометричні дослідження виконані на ультразвуковому апараті Toshiba "SSH - 140A" (Японія) та "Siemens "Sonoline SL - 250" та "Siemens "Sonoline Elegra" (Німеччина) у реальному масштабі часу за допомогою конверторного датчика 3 частотою 2-5 Мгц. Рівень гормонів ФПК визначали методом імуноферментного аналізу за допомогою набору стандартних реактивів.

Результати дослідження та їх обговорення. Показники функціонального стану ФПК вивчали в динаміці в I половині (11-12, 18-20 тижнів) та II половині (29-32 та 38-40 тижнів) вагітності.

У першому триместрі вагітності нами проведено аналіз куприково-тім'яного розміру в терміні 11-12 тижнів вагітності. Слід зазначити, що даний показник у жінок контрольної групи (КГ) та II групи вагітних достовірно не відрізнявся між собою ( $\mathrm{p}>0,05)$.

Фетометричні зміни II триместру (18-20 тиж) також носили маловиражений характер у вагітних груп спостереження: біпарієтальний розмір (БПР) мав різницю не більше 2 мм, об'єм живота (ОЖ) не більше 4 мм, а довжина стегнової кістки (ДС) не більше 2 мм (p>0,05).

При вивченні показників функціонального стану плода у вагітних із генітальним герпесом та вірусом цитомегалії в 18-20 тижнів діагностовані бради- (4,0 \%) і тахікардія (8,0 \% проти 5,7\% відповідно в КГ, $\mathrm{p}<0,05)$, у $4 \%$ - асиметрична форма затримки розвитку плода (ЗРП). Показовим $\epsilon$ те, що до цього ж терміну в пацієнток II групи в 12,0 \% спостережень відзначені субкомпенсовані дихальні рухи плода (ДРП) (1 або більш епізодів тривалістю 30-59 с; нормальна форма і частота в межах 45-60 за хвилину) проти $5,7 \%$ випадків у КГ, $<<0,05$, та в 4,0 \% виявлені декомпенсовані дихальні рухи (тривалість менше 30 с або їх відсутність за 30 хвилин спостережен- 
Таблиця 1

Рівень гормонів фетоплацентарного комплексу у вагітних дослідних груп у 18-20 тижнів

\begin{tabular}{|c|c|c|}
\hline \multirow{2}{*}{ Показник } & \multicolumn{2}{|c|}{ Групи жінок } \\
\cline { 2 - 3 } & $\begin{array}{c}\text { контрольна } \\
\mathrm{n}=35\end{array}$ & II $\mathrm{n}=50$ \\
\hline Естрадіол (нмоль/л) & $38,6 \pm 1,2$ & $24,6 \pm 2,4^{*}$ \\
\hline Прогестерон (нмоль/л) & $214,6 \pm 2,8$ & $352,6 \pm 12,6^{*}$ \\
\hline Хоріонічний гонадотропін (мМО/мл) & $62,8 \pm 5,4$ & $80,6 \pm 12,2$ \\
\hline Плацентарний лактоген (нмоль/л) & $78,6 \pm 6,2$ & $28,4 \pm 2,2$ \\
\hline Естріол (нмоль/л) & $28,5 \pm 1,3$ & $541,2 \pm 18,5$ \\
\hline Кортизол (нмоль/л) & $529,6 \pm 1,5$ & \\
\hline
\end{tabular}

Примітка. * - різниця достовірна порівняно з показниками КГ $(\mathrm{p}<0,05)$

Таблиця 2

Рівень гормонів фетоплацентарного комплексу у вагітних дослідних груп у 29-32 тижнів

\begin{tabular}{|c|c|c|}
\hline \multirow{2}{*}{ Показник } & \multicolumn{2}{|c|}{ Групи жінок } \\
\cline { 2 - 3 } & $\begin{array}{c}\text { контрольна } \\
\mathrm{n}=35\end{array}$ & II $\mathrm{n}=47$ \\
\hline Естрадіол (нмоль/л) & $54,4 \pm 0,7$ & $28,8 \pm 1,3^{*}$ \\
\hline Естріол (нмоль/л) & $96,4 \pm 2,6$ & $76,4 \pm 4,2^{*}$ \\
\hline Прогестерон (нмоль/л) & $582,2 \pm 24,5$ & $380,5 \pm 36,3^{*}$ \\
\hline Кортизол (нмоль/л) & $525,6 \pm 18,4$ & $858,6 \pm 18,6^{*}$ \\
\hline Плацентарний лактоген (нмоль/л) & $231,4 \pm 16,2$ & $190,4 \pm 14,6^{*}$ \\
\hline
\end{tabular}

Примітка. * - різниця достовірна порівняно з показниками КГ $(\mathrm{p}<0,05)$

Таблиця 3

Фетометричні показники в 38-40 тижнів (мм)

\begin{tabular}{|c|c|c|}
\hline \multirow{2}{*}{ Показник } & \multicolumn{2}{|c|}{ Групи жінок } \\
\cline { 2 - 3 } & контрольна $\mathrm{n}=35$ & II $\mathrm{n}=41$ \\
\hline Біпарістальний розмір & $95,1 \pm 1,2$ & $90,3 \pm 1,4^{* *}$ \\
\hline Діаметр живота & $106,4 \pm 1,4$ & $96,5 \pm 1,6^{* *}$ \\
\hline Довжина стегнової кістки & $72,2 \pm 1,3$ & $72,2 \pm 1,2$ \\
\hline
\end{tabular}

Примітка. * - різниця достовірна порівняно з показниками КГ $\mathrm{p}<0,05,{ }^{*} * \mathrm{p}<0,01$

ня), у 8,0 \% - субкомпенсована рухова активність (1 епізод генералізованих рухів із декількома епізодами ізольованих рухів), у 4,0 \% - декомпенсована рухова активність (відсутність генералізованих рухів) і порушений тонус плода (неповне повернення в процесі руху в початкове положення згинання) у 4,0 \% плодів.

При плацентографії в II триместрі вагітності нами виявлено, що у вагітних I групи 97,1 \% жінок мали нормальну структуру плаценти і лише в одному випадку (2,9 \%) спостерігалися патологічні зміни. У 20 \% вагітних з II групи були виявлені патологічні зміни в плаценті (варикоз судин, гіперехогенні включення (більше 30 \%), гіпертрофія плаценти та гіпотрофія плаценти, патологія міометрія в зоні плацентації). Нами виявлено передчасне старіння плаценти у 18-20 тижнів у II групі вагітних- чотири випадки (8,0 \%) 2-го ступеня зрілості та шість випадків (12,0 \%) 1-го ступеня, на відміну від вагітних КГ, де 100,0 \% випадків плацента була 0 ступеня зрілості, що притаманно цьому терміну вагітності, $\mathrm{p}<0,05$. Товщина плаценти в дослідних групах істотно не відрізнялась $(23,21 \pm 0,54$ мм проти $22,84 \pm 0,61$ мм відповідно в КГ, $\mathrm{p}>0,05)$.

При оцінці стану навколоплідних вод виявлено наступне: у II триместрі в жінок основної групи частота багатоводдя мало місце достовірно частіше (10,0\%) порівняно 3 маловоддям $(8,0 \%)$, у КГ змін об'єму навколоплідних вод взагалі не виявлено $(\mathrm{p}<0,05)$.

Аналізуючи отримані результати, проведено оцінку стану ФПК у вагітних із генітальним герпесом та вірусом цитомегалії. Виявлено, що задо- 
Гемодинамічні показники в 38-40 тижнів

\begin{tabular}{|c|c|c|}
\hline \multirow{2}{*}{ Показник } & \multicolumn{2}{|c|}{ Групи жінок } \\
\cline { 2 - 3 } & контрольна $\mathrm{n}=35$ & II $\mathrm{n}=41$ \\
\hline С/Д артерії пуповини (АП) & $3,7 \pm 0,15$ & $7,4 \pm 0,4^{* *}$ \\
\hline ІР артерії пуповини & $0,7 \pm 0,09$ & $1,9 \pm 0,1^{* *}$ \\
\hline С/Д середньо-мозкової артерії (СМА) & $6,7 \pm 0,4$ & $3,4 \pm 0,3$ \\
\hline IР середньо-мозкової артерії & $0,8 \pm 0,05$ & $0,4 \pm 0,01^{*}$ \\
\hline С/Д маткових артерій (МА) & $1,7 \pm 0,2$ & $3,4 \pm 0,3^{* *}$ \\
\hline ІР маткових артерій & $0,5 \pm 0,02$ & $1,0 \pm 0,02^{* *}$ \\
\hline
\end{tabular}

Примітка. * - різниця достовірна порівняно з показниками КГ $<<0,05, * *$ p $<0,01$. С/Д - систоло-діастолічне відновлення кривих швидкостей кровообігу, IP - індекс резистентності

Таблиця 5

Рівень гормонів фетоплацентарного комплексу в 38-40 тижнів

\begin{tabular}{|c|c|c|}
\hline \multirow{2}{*}{ Показник } & \multicolumn{2}{|c|}{ Групи жінок } \\
\cline { 2 - 3 } & $\begin{array}{c}\text { контрольна } \\
\mathrm{n}=35\end{array}$ & $\mathrm{II} \mathrm{n}=41$ \\
\hline Естрадіол (нмоль/л) E2 & $65,3 \pm 0,6$ & $45,4 \pm 1,9^{* *}$ \\
\hline Естріол (нмоль/л) E3 & $57,8 \pm 1,8$ & $28,3 \pm 2,0^{* *}$ \\
\hline Прогестерон (нмоль/л) & $607,2 \pm 17,3$ & $404,5 \pm 12,6^{* *}$ \\
\hline Кортизол (нмоль/л) & $662,1 \pm 13,7$ & $981,4 \pm 14,5^{* *}$ \\
\hline Плацентарний лактоген (нмоль/л) & $265,9 \pm 19,8$ & $200,4 \pm 12,5^{* *}$ \\
\hline
\end{tabular}

Примітка. * - різниця достовірна порівняно з показниками КГ $\mathrm{p}<0,05 ; * *<0,01$

вільний стан системи мати-плацента-плід був у 25 вагітних, що становить 50,0 \% випадків. У 50 \% вагітних діагностована плацентарна дисфункція (ПД), ступінь тяжкості якої за даними ультразвукового та доплерометричного дослідження розподілилась наступним чином: компенсована ПД дігностована в 42,0 \% випадків, субкомпенсована - у 6,0 \% спостережень, декомпенсована - у $2,0 \%$, яка завершилася завмиранням вагітності до 22 тижнів.

Отже, при оцінці функціонального стану ФПК вже у 18-20 тижнів у вагітних із генітальними інфекціями (генітальним герпесом та вірусом цитомегалії) спостерігаються перші прояви плацентарної дисфункції (ознаки компенсованих порушень стану плода, плаценти і навколоплідних вод, а в одному випадку навіть декомпенсовані порушення).

Відомо, що гормони прогестерон (ПГ), естрадіол (Е2) та хоріонічний гонадотропін (ХГ) мають велике значення для фізіологічного перебігу вагітності і нормального розвитку плода під час фізіологічної вагітності. Рівень гормонів $€$ основою для виявлення порушення функції ФПК і стану плода. Нами проведено вивчення рівня гормонів ФПК. Дані про динаміку основних гормонів у сироватці крові обстежених жінок наведені в таблиці 1 .
Згідно 3 даними нашого дослідження у вагітних основної групи, починаючи 3 18-го тижня, відзначалося достовірне зниження рівня ПГ

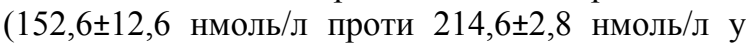
групі контролю, $<<0,05)$ та ХГ $(36,6 \pm 2,6$ мМО/мл проти $62,8 \pm 5,4$ мМО/мл у групі контролю, $\mathrm{p}<0,05)$. Клінічно це проявлялось у симптомах тривалої загрози переривання вагітності. Рівень естріолу в сироватці крові характеризує стан функції ФПК. У вагітних II групи $з$ 18-го тижня вагітності рівень Е2 достовірно нижче $(24,6 \pm 2,4$ нмоль/л), ніж у вагітних КГ $(38,6 \pm 1,2$ нмоль/л, $\mathrm{p}<0,05)$. Синхронне зниження рівня ПГ та Е2 спостерігалося при загрозі переривання вагітності на тлі кров'янистих виділень, що свідчить про перші клінічні ознаки розвитку ПД. Плацентарний лактоген (ПЛ) синтезується тільки клітинами трофобласта. Наявність лише одного джерела його синтезу дозволяє використовувати ПЛ для діагностики функціонального стану плаценти. Як видно з таблиці 1, у вагітних II групи рівень ПЛ на 18-му тижні практично не відрізнявся $(80,6 \pm 12,2$ нмоль/л) від рівня у вагітних КГ (78,6 $\pm 6,2$ нмоль/л, $\mathrm{p}>0,05)$.

Таким чином, результати проведених досліджень рівня гормонів ФПК свідчать про те, що розвиток фізіологічної вагітності супроводжується прогресивним синхронним 
збільшенням секреції ПГ, Е2, ПЛ. У II групі вагітних рівень ПГ та Е2 достовірно нижче, ніж у КГ. Це дає підстави зарахувати вагітних із генітальним герпесом та вірусом цитомегалії до групи ризику розвитку первинної ПД та невиношування. У зв'язку з цим гормональна діагностика функціонального стану ФПК має бути рекомендована даній групі вагітних із ранніх термінів гестації. Треба зазначити, що у II групі вагітних з 20го до 22-го тижнів вагітності завмерло ще дві вагітності, що разом склало три випадки завмирання $(6,0 \%)$ до 22 тижнів, що свідчить про негативний вплив геніальних інфекцій на перебіг вагітності.

Фетометричні зміни на 29-32-му тижні у вагітних із генітальним герпесом та вірусом цитомегалії, порівняно з вагітними КГ, мали достовірне розходження лише по одному показнику (БПР голівки плода) - 73,44 $\pm 1,26$ мм проти $81,44 \pm 0,99$ мм відповідно до КГ $\mathrm{p}<0,05$. Аналізуючи дані, треба зазначити, що на 29-32-му тижні частота асиметричної форми ЗРП зросла до $19,1 \%$; порушення серцевої діяльності плода траплялися в 23,4 \% спостережень, субкомпенсовані форми порушень ДРП збільшились до 19,1%, його рухової активності - до 21,2 \%. Прогностично несприятливою $є$ поява в одиничних випадках декомпенсованих форм порушень ДРП і його рухової активності (2,1 \%). Дуже показовим $є$ те, що в цих жінок відбулися передчасні пологи в 31-33-му тижнях при антенатальній загибелі плодів, 3 діагностованим внутрішньоутробним інфікуванням плодів.

Після 29-го тижня достовірно починає збільшуватися кількість порушень в плаценті, що прогресивно наростає до кінця вагітності. У КГ лише 5,7 \% мають патологічні зміни у вигляді кальцинатів. У II групі вагітних достовірно вище - 34,0 \% проти 5,7 \% у КГ, p<0,05. При цьому передчасне дозрівання плаценти 2-го ступеня спостерігається в КГ лише в 11,4 \% випадків, тоді як у жінок II групи цей показник досягає 25,5\% $(\mathrm{p}<0,05)$ і навіть у п'яти випадках $(10,6 \%)$ спостерігалося передчасне дозрівання 3-го ступеня . Товщина плаценти на 29-32-му тижні в КГ склала $31,40 \pm 0,55$, та не мала достовірних відмінностей

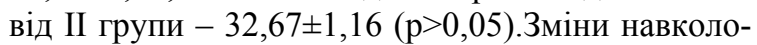
плідних вод достовірно відрізняється $(\mathrm{p}<0,05)$, якщо в КГ лише один випадок багатоводдя $(2,9$ \%), то в II групі вагітних збільшилась як кількість багатоводдя до 19,1 \%, так і кількість маловоддя до $14,9 \%$.

Таким чином, за результатами проведеного дослідження нами проведено оцінку стану ФПК на 29-32-му тижні вагітності і ПД компенсована була діагностована в 44,7 \%; у 19,1 \% випадків відзначена субкомпенсована і в 2,1 \% випадків некомпенсована.

Одним із патогенетичних механізмів розвитку ПД є порушення матково-плацентарного і фетоплацентарного кровотоку, що призводить до дистресу плода та розвитку синдрому затримки росту плода (СЗРП). Гемодинамічні порушення в 29-32-му тижні гестації характеризувалися порушенням кровообігу в артерії пуповини (С/Д - 3 $3,0 \pm 0,04$ у КГ до 4,8 $\pm 0,2$ у II групі, IP - 3 0,7 $\pm 0,4$ у КГ до 1,2 $\pm 0,2$ у II групі; $<<0,05)$ і в маткових ар-

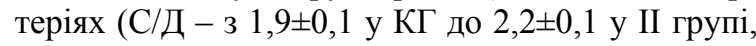
IP - 3 0,5 $\pm 0,01$ у КГ до $0,7 \pm 0,01$ у II групі; $p<0,05$ ) на тлі збереженого кровообігу в середньомозковій артерії плода в обох групах (С/Д - 3 $6,7 \pm 0,05$ у КГ до $6,1 \pm 0,2$ у II групі і IP - $30,7 \pm 0,05$ у КГ до 0,6 $\pm 0,02$ у II групі).

Розглядаючи зміни рівня гормонів ФПК на 29-32-му тижні вагітності слід зазначити, що розпочинаючи з 29-го тижня рівень ПГ у вагітних 3 генітальним герпесом та вірусом цитомегалії становив - 380,5 $\pm 36,3$ нмоль/л і був достовірно нижче $(\mathrm{p}<0,05)$, ніж у вагітних КГ $-582,2 \pm 24,5$ нмоль/л. На наш погляд, це можливо пояснити тим, що в ці терміни у вагітних із генітальними інфекціями розвивається ПД. Клінічно це проявлялось у симптомах загрози передчасних пологів. Дані про динаміку рівня гормонів у сироватці крові обстежених жінок наведені в таблиці 2.

3 29-го тижня вагітності рівень Е2 у групі порівняння достовірно відрізняється від КГ $(54,4 \pm 0,7$ нмоль/л у КГ проти 28,8 $\pm 1,3$ нмоль/л в II групі, p<0,05), ПГ $(380,5 \pm 36,3$ нмоль/л проти $582,2 \pm 24,5$ нмоль/л у II групі вагітних відповідно, $\mathrm{p}<0,05)$. Найбільш виражений характер мала різниця вмісту естріолу (Е3) та кортизолу (Кр) у сироватці крові відносно КГ у ІІ групі, що виявлялася зниженням рівня Е3 (до 76,4 $\pm 4,2$ нмоль/л проти 96,4 $\pm 2,6$ нмоль/л у КГ; $p<0,05)$ на фоні одночасного збільшення вмісту Кр (до 858,6 $\pm 18,6$ нмоль/л проти 582,2 $\pm 24,5$ нмоль/л у КГ; р $<0,05)$.

Зміни функціонального стану ФПК на 29-32му тижні мають ще більш виражений характер, про що свідчать результати наших досліджень: збільшилася частота асиметричної форми затримки розвитку плода та порушення його дихальної і рухової активності; передчасне дозрівання плаценти, збільшення випадків зміни об єму навколоплідних вод та наростання гормональної недостатності ФПК і також появою гемодинамічних порушень. Розробка нової адекватної медикаментозної корекції дасть можливість запобігти акушерським та перинатальним ускладненням.

Напередодні розродження показники функціонального стану плода у вагітних із генітальним герпесом та вірусом цитомегалії характеризується високою частотою СЗРП (29,97 \%); порушеннями серцевого ритму (брадикардія - 11,8 \% i тахікардія - 17,6 \%); суб- і декомпенсованими порушеннями дихальної (20,6 \% та 5,6 \% відповідно) і рухової активності плода (суб- 29,4 \% i декомпенсовані - 5,9\%); а також змінами тонусу плода $(8,8 \%)$. При оцінці основних змін плаценти і навколоплідних вод варто звернути увагу на достовірне збільшення передчасного старіння плаценти (до 47,1 \%) та високий рівень мало$(23,5 \%)$ і багатоводдя (35,3\%). При оцінці функціонального стану ФПК перед розродженням 
задовільний стан ФПК спостерігався у 38,2 \% випадків вагітних II групи, ПД була діагностована в $61,8 \%$ (компенсована - у 29,4 \%, субкомпенсована - у 26,5 \% і декомпенсована - відповідно в 5,9\% спостережень.

Аналізуючи основні фетометричні показники в 38-40 тижнів (табл. 3), виявлено достовірне $(\mathrm{p}<0,05)$ зниження двох показників розміру плода (БПР голівки та об'єму живота).

Дослідження кровотоку в ФПК перед розродженням показало наростання порушень матково-плацентарно-плодового кровообігу (табл. 4).

Рівень гормонів ФПК також змінився: зменшився рівень Е2 (до 45,4 $\pm 1,9$ нмоль/л проти $65,3 \pm 0,6$ нмоль/л у КГ; р<0,05), Е3 (до 28,3 $\pm 2,0$ нмоль/л проти 57,8 $\pm 1,8$ нмоль/л у КГ; р $<0,01)$, ПГ

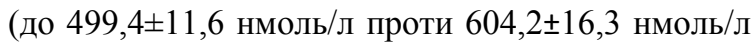
у КГ; $<<0,05$ ) і ПЛ (до 200,4 $\pm 12,5$ нмоль/л проти $265,9 \pm 19,8$ нмоль/л у КГ; р<0,05) і збільшився

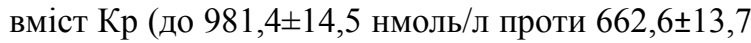
нмоль/л у КГ; р<0,01) (табл. 5).

Таким чином, аналіз стану ФПК у вагітних із генітальним герпесом та вірусом цитомегалії показав, що напередодні розродження спостерігається високий рівень передчасного дозрівання плаценти й зміни об'єму навколоплідних вод, за рахунок чого з`являються гемодинамічні порушення та зміна рівня гормонів ФПК, в основному, субкомпенсованого характеру, але в деяких випадках і декомпенсованого, що спричиняє високу частоту дистресу плода різного ступеня тяжкості та СЗРП. Формування та функціональний стан ФПК у вагітних цієї групи супроводжуються значним рівнем порушень із боку функціонального стану плода, які починаються на 18-20-му тижні, та максимальні зміни мають місце напередодні розродження: зміни серцевого ритму (з 12,0 \% до $29,4 \%$ ); дихальної (з $16,0 \%$ до $26,4 \%$ ) та рухової активності плода (з $12,0 \%$ до $36,3 \%$ ), тонусу (з 4,0 \% до 8,8 \%); плаценти (дозрівання випереджає термін гестації (з 20,0 \% до 47,1 \%) і об'єму навколоплідних вод (мало- $38,0 \%$ до 23,5 \% та багатоводдя з 10,0 \% до 35,3 \%) на тлі виражених гемодинамічних порушень у ФПК (порушення кровообігу в артерії пуповини та маткових артеріях) і зміна рівня гормонів ФПК (зниження вмісту естріолу, прогестерону, хоріонічного гонадотропіну і плацентарного лактогену на тлі збільшення рівня кортизолу).

\section{Висновки}

1. При оцінці функціонального стану фетоплацентарного комплексу, вже у 18-20 тижнів у жінок із генітальним герпесом та вірусом цитомегалії спостерігаються перші ознаки компенсованих порушень стану плода, плаценти і навколоплідних вод.

2. Аналіз стану фетоплацентарного комплексу у вагітних із генітальним герпесом та вірусом цитомегалії показав, що напередодні розродження він характеризується високим рівнем передчасного дозрівання плаценти й зміни об'єму навколоплідних вод, за рахунок чого з'являються гемодинамічні порушення, змінюється рівень гормонів фетоплацентарного комплексу, розвивається плацентарна дисфункція, в основному, субкомпенсованого характеру, але в деяких випадках і декомпенсованого, що спричиняє порушення з боку функціонального стану плода та високу частоту дистресу плода різного ступеня тяжкості та синдрому затримки росту плода.

3. Отримані результати дослідження свідчать про необхідність включення в лікувальний комплекс у вагітних носіїв генітального герпесу та вірусу цитомегалії препаратів, що сприяють нормалізації газообміну в системі «матиплацента-плід» і покращують процеси метаболізму в плаценті.

Перспективи подальших досліджень. Для більш чіткого розуміння механізмів порушень у системі мати-плацента-плід у вагітних із генітальними інфекціями, які складають групу ризику внутрішньоутробного інфікування, та враховуючи нерозривний зв'язок зміни рівня гормонів 3 імунною системою, у подальшому плануємо провести дослідження системного імунітету в групах спостереження.

\section{Література}

1. Булавенко О.В. Діагностичні критерії розвитку дистресу плода у вагітних з різними типами герпетичної інфекції / О.В. Булавенко, В.В. Кливак // Актуал. пит. педіатрії, акуш. та гінекол. - 2015. - № 2. - С. 78-80.

2. Каграманова С.М. Ранняя диагностика нарушений внутриутробного состояния плода у пациенток с цитомегаловирусной инфекцией / С.М. Каграманова, Н.М. (мл) Шамсадинская // Успехи соврем. естествознания. - 2011. - № 3. - С. 13-17.

3. Мирзоева Т.Н. Морфофункциональные изменения плаценты при цитомегаловирусной инфекции / Т.Н. Мирзоева // Междунар. мед. ж. - 2010. - № 2. C. $44-48$.

4. Baker D.A. Issues and management of herpes in pregnancy / D.A. Baker // Int. J. Fertil. Women Med. - 2012. Vol. 47, № 3. - P. 129-139.

\section{ОЦЕНКА СОСТОЯНИЯ ФЕТОПЛАЦЕНТАРНОГО КОМПЛЕКСА У БЕРЕМЕННЫХ С ГЕНИТАЛЬНЫМ ГЕРПЕСОМ И ВИРУСОМ ЦИТОМЕГАЛИИ}

\section{Н.M. Садыгов}

Резюме. Функциональное состояние фетоплацентарного комплекса (ФПК) у беременных с генитальным герпесом и вирусом цитомегалии сопровождается развитием плацентарной дисфункции, которая формируется на 18 20-й неделе и клинически проявляется во втором и третьем триместре беременности. Клинически это проявляется тахикардией у внутриутробного плода (с 12,0 \% до 29,4 \%); изменением дыхательной (с 16,0 \% до 26,4 \%), двигате- 
льной активности (с 12,0 \% до 36,3 \%) и тонуса плода (с 4,0 \% до 8,8 \%); преждевременным старением плаценты (с $20,0 \%$ до 47,1 \%), изменением количества околоплодных вод (маловодие с 8,0 \% до 23,5 \% и многоводие с $10,0 \%$ до $35,3 \%$ ) на фоне выраженных гемодинамических нарушений в ФПК (нарушение кровообращения в артерии пуповины и в маточных артериях); изменением уровня гормонов ФПК - снижение содержания эстриола, прогестерона, хорионического гонадотропина и плацентарного лактогена, на фоне увеличения уровня кортизола.

Ключевые слова: вирус герпеса, цитомегаловирус, беременность, фетоплацентарный комплекс.

\section{EVALUATION OF THE FETOPLACENTACOMPLEX IN PREGNANT WOMEN WITH GENITAL HERPES AND CYTOMEGALOVIRUS INFECTION}

\section{Y.M. Sadyhov}

Abstract. Formation and functional status of FPC in pregnant carriers of HSV and CMV infection accompanied by a significant level of various disorders that start at 18-20 weeks and progressing to delivery. These include increasing the frequency of changes in heart rate (from $12,0 \%$ to $29,4 \%$ ); respiratory (from $16,0 \%$ to $26,4 \%$ ), motor activity (from $12,0 \%$ to $36,3 \%$ ) and fetal tone (from $4,0 \%$ to $8,8 \%$ ); disorders of the placenta (maturing ahead gestation period (from $20,0 \%$ to $47,1 \%$ ) and the volume of amniotic fluid (with low $-8,0 \%$ to $23,5 \%$ and $10,0 \%$ of polyhydramnios to $35,3 \%$ ) against the backdrop of severe hemodynamic disturbances in FPC (impaired blood flow in the umbilical artery and uterine arteries in) endocrinological disorders - reduction of estriol, progesterone, human chorionic gonadotropin and placental lactogen, against the background of increased levels of cortisol.

Key words: herpes virus, cytomegalovirus, pregnancy, fetoplacental complex.

SHEE «Uzhhorod national university»

Рецензент - д. мед. н. І.В. Каліновська
Buk. Med. Herald. - 2016. - Vol. 20, № 3 (79). - P. 155-160

Надійшла до редакції 22.06.2016 року

(C) Ю.М. Садигов, 2016 